\title{
SOCIO-PSYCHOLOGICAL MECHANISMS OF HUMAN KINDNESS IN THE FORMATION OF THE MICROENVIRONMENT IN THE FAMILY
}

\author{
Zubayda Fozilovna Sharopova \\ Independent Researcher, Senior Teacher of the Department Physical Education and Sport, \\ Tashkent State Agrarian University, Tashkent, Uzbekistan
}

Marat Normadovich Tojiboyev

Teacher of the Department Physical Education and Sport, Tashkent State Agrarian University, Tashkent, Uzbekistan

Article DOI: $\underline{\text { https://doi.org/10.36713/epra4433 }}$

\begin{abstract}
In this article, kindness is the highest and most sincere love of a person for existence, the expression of individual high human feelings in society in an impressive, constant interpersonal social relationship, human kindness, its importance in social relations, categories, its evaluation through quantitative analysis, laughter, smiles, doing good, sincerity, helping, the emergence of mutual affection, but there are also factors that extinguish affection, such as slapping in the face, pushing from the chest, abusing, comparing to others, over-controlling, discrediting in front of others, not supporting when needed, in interpersonal relationships, especially today, to the child by the parents, the parents by the children, the grandchildren by the grandparents, the mother-in-law, the brothers, the relatives, methods of increasing the affection of members of society in general for each other have been analyzed.
\end{abstract}

KEYWORDS: social relations, social roles, kindness, affection, environment of kindness, service, expression of kindness, contact and non-contact kindness categories.

\section{THE URGENCY OF THE SUBJECT}

The concept of kindness, which has been relevant in all times and eras, has recently become one of the topics that has caused widespread discussion among people. This can be seen in conversations with different segments of the population, in people's discussions, in the media, in plays, in movies, in music, in street talk.

"He has no kindness for his parents", "He can't be kind with his child", "If he gave a little love, the bride would not leave", "Add a little kindness", "Where is the kindness market", "There is no kindness", "be mercy", Sentences like these have become a frequent part of our daily lives. It seems to me that this is the core of a number of social problems that have become a social problem. This can be especially seen in the upbringing of children, in the relationship of spouses, in-laws, brothers, sisters, and children to their parents. Cruelty is causing the closest people to distance themselves from each other today. So let's do a little analysis of the concept of kindness.

Scientifically, the concept of compassion, kindness is related to a number of disciplines such as philosophy, psychology, theology, and sociology. We focus on the social aspect of the issue. In general, what is the social significance of the feeling of kindness in a person? How does it seen in interpersonal relationships? How to increase the feeling of kindness in society? This has been one of the most pressing issues of all time.

KINDNESS - it is man's highest and most sincere love to the universe. In society, an individual's high human feelings can be defined as the expression of emotions in interpersonal social relations on an impressive, constant basis.

Kindness, on the other hand, helps a person to embrace a certain environment in society - a sense of calm, trust, sincerity, freedom, happiness. They give a person a sense of happiness and confidence in life, hope for goodness, a sense of aspiration. At the same time, it 


\section{SJIF Impact Factor: 7.001| ISI I.F.Value:1.241| Journal DOI: 10.36713/epra2016 ISSN: 2455-7838(Online) EPRA International Journal of Research and Development (IJRD)}

not only prevents the processes of disagreement and conflict in social relations, but also encourages consensus and cooperation.

Lack of kindness for a person causes a number of problems in society. One of the factors that lead to aggression in a child's character is lack of mothers affection, the need for parental upbringing.

Further strengthening the atmosphere of kindness in society, increasing the love of parents, children, grandparents, grandchildren, brothers-in-law, brothers, relatives, and members of society in general, especially in today's society, strengthens stability in society.

It seems to us that the concept of compassion, kindness is at the heart of many social problems that have become a problem of society today. This can be especially seen in the upbringing of children, in the relationship of spouses, in-laws, brothers, sisters, and children to their parents.

The passionate scientist, Professor G.B Shoumarov and his students' several years of scientific research in this area are commendable. But these studies do not allow us to take the problem to a completely positive level. The analysis shows that as a result of the research done so far, about fifty concepts have been scientifically clarified. In order to fully express affection in social relations, it will be necessary to take more than a hundred terms out of the mire of abstraction, to define and analyze them clearly.

Recently, the research of professors M.Kuronov and M.Bekmurodov in this area is also yielding positive results.

\section{METHODOLOGY}

It relied on methods such as interview, observation, content analysis, and a "scale to assess the level of kindness in interpersonal relationships".

\section{EMPIRICAL ANALYSIS}

It is well known that a social relationship represents a social relationship that arises from the fulfillment of the social status and social roles occupied by members of society. It reflects the relationships that take place directly or indirectly in society, between individuals and social groups. They arise as a result of influence and interaction, and take the form of dialogue, cooperation, conflict, compromise, alliance, association. Communication is manifested in the exchange of information, direct communication of their desires and inclinations to others by members of society in direct social relations.

The fact that people show kindness to each other in communication symbolizes closeness, understanding, solidarity. Human kindness gives people feelings such as peace, happiness, sincerity, confidence, joy. In sociology, this is studied in the context of affective action as one of the four most important social movements.

The family encyclopedia focuses on concepts such as kindness, its expression, and cruelty. "Kindness is a person's sincere love for their relatives, loved ones, and the person in general. Although the environment in which children grow up in the family, their parents, and their attitudes toward children are the same, the expression of kindness is different. Kindness is not only formed during life, its basis is in many respects hereditary" [2].

According to many scholars and thinkers, the highest, most sincere love in human relations is the mother's love for her child.

We conducted a study to determine the social aspects of how a mother's love for her child is formed. To do this, interviews with mothers aged 28-55 were conducted in 5 groups of 20 people each. In the course of the research, the groups discussed the composition, formation and development of the mother's relationship with the child. It was the reasons why the mother became attached to her child, or more precisely, the reasons why she became attached. Let us consider in real life the emergence of endless love for the child.

Here are some of the discussions with them:

-"It is said that a mother's love for her child is highest feeling, how do you feel about that?".

- The answers are basically the same: "Yes, unique."

- " How do you understand the feeling of kindness?".

- "It is a very high sincere feeling", "It is a divine feeling", "Words cannot describe it" such answers were given.

When group members are asked to explain the current situation in detail and what kind of relationship it will be: "Carrying in the body for nine months, giving birth with fear and suffering, breastfeeding, feeding, singing lullaby, dressing, bathing, healing" We got answers like this, etc..

Another situation: As a result of many years of service, the employee's love for the office ... Our interlocutor worked as a teacher at school number 21 for 31 years.

- My school, where I have worked for many years, always attracts my affection, says our interlocutor.

- Did you also work at School No. 22?

- No, I only worked at School No. 21.

- Do you feel like you're walking past School No. 21 , where you've always worked, as you walk past School No. 22? Both are schools.

- Of course not. As I walk past School No. 21 where I work, I get some special feelings, emotions, memories. I feel even if there is a small change. I'd like to go inside. Sometimes I even go in. Even though most of my co-workers are retired, it still attracts me.

- What about passing in front of School No. 22? It's a school, there are teachers, students, a principal, a desk, a table, a chair, it's all like in school number 21, isn't it?

- There is no such feelings.

- Is it just like passing in front of the ordinary building? 


\section{SJIF Impact Factor: 7.001| ISI I.F.Value:1.241| Journal DOI: 10.36713/epra2016 ISSN: 2455-7838(Online) EPRA International Journal of Research and Development (IJRD)} building.

- Yes, just like passing in front of an ordinary

- If the building of the school where you work collapses and is replaced by a multi-storey building, will you feel the same way as you pass in front of it?

- No. It would be seemed strange to me.

We spoke with several employees who have worked in the same company for many years. We got the same answer from everyone.

This means that man, because of his service, causes such a connection not only with man, or with the living, but also with the inanimate.

Another situation:

- I have three uncles. One of them loves me more than the others. But I have the same attitude towards all three of them. I'm looking for reasons. I was three years old when he returned from military service, "he said.

- Since we lived in the next yard, he spent more time with me and played together. He was carrying me on his shoulders. When I watch even family photo albums, I saw a lot of pictures with my uncle. So far, if he see me at weddings and celebrations, he definitely come and sit in front of me. His love for my other brothers is not as like to me. Hence, kindness can also be formed unilaterally on the basis of labor.

Imagine: you are talking to a stranger you have never met before. You have no information about him, you don't even know his name. What kind of affection can there be with a person with whom you have never been in a social relationship before. Of course, these feelings are a gradual process. So, kindness represents a certain level of closeness in these interpersonal relationships.

Now, based on the above, we are looking for an answer to the question of how to create an increase in the level of kindness in interpersonal relationships.

Let us conditionally accept that in social relations love and kindness is the product of work, service. Increasing kindness does not require much effort on our part. Use your children in relation to each other. Because this method increases the mutual affection between them. Remember, clapping comes out of both hands. What people do for each other is small, and trivial things increase the love kindness between them. It is good that the number of these actions is greater. Apply this exercise to yourself and your loved ones. Mutual service becomes an important means of creating mutual love. A mathematician friend of mine called it the "Formula for Enhancing kindness."

Laughter, smiles, doing good, sincerity, helping will cause mutual kindness in a person. At the same time, there are factors that can dampen affection, such as slapping in the face, pushing from the chest, sighing, comparing to others, over-controlling, hitting the ground in front of others, not supporting when needed.

It is also a form of expressing affection when calling for loved ones attention to much. For example, some mothers focus on their children to the point of forgetting their own lives, or it can be said that it is an abused kindness for children to deviate from the norm by taking advantage of parental kindness.

Kindness can be felt in the eyes, in the palms of the hands, in intimacy, in hugs, kisses, in missing. People look at each other with compassion, when they caress their foreheads with their hands, when they pat them on the shoulders, when they hold each other close to each other, when they hug, when they kiss, when they greet each other with longing. So it is possible to take, give, increase, decrease and even overuse love and kindness.

As a result of the analysis of about a hundred categories related to love and kindness, we have divided them into contact (lat. Contactus - touch; connection) and non-contact forms of communication [7].

Today, a clear, practical study of any relationship is required. Therefore, we cannot fully use the concept of kindness and its expression in the life of society without a clear, practical analysis. The problems in this regard are growing day by day. Of course, this is not a simple process. It is also very difficult to achieve a definite result. The reason is that we are talking about an emotional, i.e., a dynamic relationship based on qualitative methods. In addition, affective behavior will need to be quantified. To this end, we have taken a terminological approach to important aspects of interpersonal relationships in expressing affection. We collected them using a content analysis method. We analyzed about a hundred categories by experts and singled them out as concepts that express kindness. Based on the "assessment scale", we asked respondents to evaluate these categories. To date, we have compiled eight surveys based on these scale units, but differing in subject matter.

The following is an example of a "Questionnaire to Assess the Level of Motherhood in a Mother-Child Relationship". The questionnaire is based on an "Assessment Scale," in which the numerical representation of an action is determined by the objects being written or evaluated, not by the researcher. It will be necessary to develop the views of the respondents on the object of interest to the researcher. Based on the recommended scale, it is possible to assess the level of kindness in interpersonal relationships. Of course, research is being done to further improve this. In the questionnaire, the concepts that define kindness are listed as units of scale. The questionnaire assesses the level of kindness of one person (applicant) in the relationship with another person.

The person completing the questionnaire puts the daily average or overall average relationship on the scale in numerical order (i.e., how many times).

The numbers entered are summarized by the interviewer or electronic program and divided by 16 . The result is an index of kindness shown by the applicant:

$$
M c / t=M
$$

Here: $M c$ - kindness number, $t$ - time, $M$ index of kindness. 
Table 1

Questionnaire survey

Full filling person:

N.S.P.:

Age:

Sex:

Social background:

Job:

Address:
WHO IS FILLED FOR:

N.S.P.:

Age:

Sex:

Address:

Table 2

KINDNESS ASSESSMENT QUESTIONNAIRE:

(A mother's love for her child)

\begin{tabular}{|c|c|c|}
\hline № & Concepts & $\begin{array}{l}\text { The number of activities per day (can } \\
\text { be determined approximately) }\end{array}$ \\
\hline \multicolumn{3}{|c|}{ 1. Contact forms of kindness: } \\
\hline 1. & Hugging & \\
\hline 2. & Shake hands, greet & \\
\hline 3. & Kissing on the face & \\
\hline 4. & touching face & \\
\hline 5. & Rubbing head & \\
\hline 6. & Feeding & \\
\hline 7. & Breastfeeding & \\
\hline 8. & Tapping on his shoulder & \\
\hline 9. & Rubbing his shoulder & \\
\hline 10. & Kissing on the forehead & \\
\hline 11. & caressing forehead & \\
\hline 12. & Carrying & \\
\hline 13. & carry on the back & \\
\hline 14. & Caress up under the armpits & \\
\hline 15. & Play a role together & \\
\hline 16. & Dressing & \\
\hline 17. & Giving gifts and presents to please & \\
\hline 18. & Tickle & \\
\hline 19. & Lift up and put to bed when sleeping & \\
\hline 20. & Kissing and cuddling while sleeping & \\
\hline 21. & Wake up in the morning with a hug & \\
\hline 22. & Waiting, watching & \\
\hline \multicolumn{3}{|c|}{ 2. Contactless forms of kindness: } \\
\hline 23. & A sincere smile & \\
\hline 24. & Showing sincere respect by placing your hand on your chest & \\
\hline 25. & Squeezing both eyes & \\
\hline 26. & Shake hands and say goodbye & \\
\hline 27. & Conversation (with sincere, humorous words) & \\
\hline 28. & Saying his name affectionately & \\
\hline 29. & Traveling together & \\
\hline 30. & Promote & \\
\hline 31. & Intimate conversation & \\
\hline 32. & Telling a fairy tale & \\
\hline 33. & Listening to the child & \\
\hline 34. & $\begin{array}{l}\text { "I love you ", "my strong boy", "Mommy", " My dear" to say } \\
\text { affectionate words like this }\end{array}$ & \\
\hline 35. & Consideration of wishes & \\
\hline
\end{tabular}

(6) 2020 EPRA IJRD | Journal DOI: https://doi.org/10.36713/epra2016_ | www.eprajournals.com |103 | 


\section{EPRA International Journal of Research and Development (IJRD)}

Volume: 5 | Issue: 5 | May 2020

- Peer Reviewed Journal

\begin{tabular}{|c|c|c|}
\hline 36. & Praise & \\
\hline 37. & Protection & \\
\hline 38. & Dancing & \\
\hline 39. & sing a lullaby & \\
\hline 40. & help in memorizing poetry & \\
\hline 41. & Blessing & \\
\hline 42. & Hearing the problems & \\
\hline 43. & Sing a song & \\
\hline 44. & Watching cartoons and movies together & \\
\hline 45. & Give useful tips & \\
\hline 46. & Concern for health & \\
\hline 47. & Send an SMS & \\
\hline 48. & Talking by telegram & \\
\hline 49. & Send emoticon jokes & \\
\hline 50. & Communicate online & \\
\hline \multicolumn{2}{|c|}{$\begin{array}{l}\text { In our example, the number of operations } \\
\text { performed by the questionnaire was } 48 \text {. If we divide the } \\
\text { result by } 16^{1} \text {, the product is } 3 \text {. So the kindness index is } \\
3 \text {. } \\
\text { The average index on the scale is } 7 \text { points for } 0-5 \\
\text { years, } 3 \text { points for } 6-15 \text { years, } 2 \text { points for } 15 \text { years and } \\
\text { older }^{2} \text {. Recommendations are issued to the client on the } \\
\text { basis of units on the scale, based on the average age, by } \\
\text { a specialist or on the basis of an electronic program. } \\
\text { For example, if the kindness index is } 3 \text { points as } \\
\text { mentioned above and the object is } 4 \text { years old, it is a } \\
\text { low indicator. Because at this age the index is the norm }\end{array}$} & $\begin{array}{l}\text { supplemented by an assessment of the level of } \\
\text { kindness. } \\
\text { It is important to know how much the object feels } \\
\text { or understands the kindness given by the subject. It is } \\
\text { therefore important to determine the difference between } \\
\text { a given kindness and a received kindness on the basis of } \\
\text { a comparative analysis and to determine the dynamics } \\
\text { of misunderstandings. Here you can also see the } \\
\text { difference in how much the mother and child, the } \\
\text { mother-in-law and the daughter-in-law understand each } \\
\text { other. This will help resolve any disagreements that may } \\
\text { arise in the future. }\end{array}$ \\
\hline
\end{tabular}

if the average is 7 points. In this case, the specialist pays attention to the scales of 0 and below, and develops recommendations on the number of times to increase these indicators, putting numbers in the units of the scale and the missing contact and non-contact kindness to the object.

\section{WHO CAN FILL OUT THIS SURVEY?}

The "Questionnaire to assess the level of kindness in interpersonal relationships" can be filled by anyone. It shows the kindness and care of one person towards another.

In family relationships:

- mother's to child;

- father's to child;

- sister's to sister;

- brother's to brother;

- grandfather's to grandchild;

- grandmother's to grandchild;

- mother in law's to daughter in law

${ }^{1}$ A day and night is 24 hours, of which 8 hours is pure sleep, and we subtract 16 . This was marked as a period of daily expression of kindness.

${ }^{2}$ Average indices such as 7, 5, 2 were obtained. As you grow older, the distance between interpersonal social distances increases. This in turn leads to a decrease in the index of expression of kindness. Also, the average ratio of the results obtained from the respondents was taken as the average normative indicator and the rate of differentiation according to age was determined. In generalizing the units of scale, the types of audialist, visualist, knesthetic, discrete personality of the subject's perception of information from the outside world were taken into account.

\section{CONCLUSION}

Kindness gives a person feelings of peace, mutual trust, sincerity, freedom, happiness. It awakens in a person the confidence to live, the hope for goodness, the feeling of aspiration. It also prevents disagreements and conflict processes and strengthens consensus and cooperation.

In interpersonal relationships, especially today, increasing the love of parents for their children, parents of children, grandchildren of grandparents, mother-inlaw, brothers, relatives, and members of society in general strengthens stability. Lack of kindness leads to aggression in the child's character and leads to the emergence of various negative vices in society. It serves as a tool for the effective organization of preventive work against crime.

The sense of kindness has a special significance in social relations as a product of mutual service, and the ways of showing kindness in interpersonal relations, receiving it, giving it, increasing it, decreasing it have been analyzed.

About sixty terms related to the concept of kindness were evaluated as categories that express compassion in interpersonal relationships. By further expanding the categories that represent this concept, it is possible to eliminate ambiguities in this regard and achieve a positive attitude in social relations.

About a hundred categories collected by the method of content analysis were analyzed by experts, and the selected ones were formed as units of the "Scale 


\section{SJIF Impact Factor: 7.001| ISI I.F.Value:1.241| Journal DOI: 10.36713/epra2016 ISSN: 2455-7838(Online) EPRA International Journal of Research and Development (IJRD)}

of assessment of the level of kindness in interpersonal relationships." Eight surveys were conducted to assess this relationship, but differing in subject matter. Positive conclusions were obtained from surveys in expert and experimental studies.

Qualities such as aggression and cruelty were interpreted as psychological and sociological consequences of cruelty.

These approaches are important in modern family relations, as they are aimed at increasing the sincere love of family members for each other, the formation of new traditions and customs.

\section{Recommendations for strengthening the atmosphere of kindness in Uzbek families}

- make it a habit for your child to live by strict adherence to family discipline.

- instill in your child the habit of doing everything assigned to him in a fluffy, mediocre, and beautiful way, teaching him to think that whatever he does, it should be more graceful and beautiful.

- teach your children to do each other's work. This leads to the strengthening of the bonds of kindness between them.

- have a friendly conversation with the child for 40 minutes every day on various topics (school, without emphasizing the responsibility for his studies, that is, without excessive advice).

- As a parent 5-10 times a day, show your children that you love him or her in different ways.

- At least 3 times a day, tell about the good behavior, good deeds your child did to other relatives in the family. Your praise will surely reach him.

- do outdoor activities with the child 2 or 3 times a week (walking, playing sports, driving).

- eat dinner together as a family 3-4 times a week for family counseling and conversation.

- allow the child to speak fully for 10 to 12 minutes each day: in a quiet, peaceful place, listen, allowing the child to say what he or she wants, without boundaries or notes.

Every day, find kindness stories about the lives of our great ancestors for your child, teach him or her, and turn the discussion together into a family picture.

Exaggerate the lives of peaceful neighbors and encourage them to learn from them.

Make it a habit for your child to take care of their brother or sister, and in return, emphasize that it is good to always show kindness without expecting an equal return from them, and that this work will be rewarded by Allah.

- Every day before going to bed to teach a child the basics of life, you can express your consent as a father by saying, "I felt very happy when you did such and such a good deed," "Looking at your brother is a big deal," "I am proud that you kept our agreement." let him know that you are proud of him. for him:
- Stroking the back of the head - symbolizes kindness and compassion;

- putting a hand on his head is an expression of pride;

- Placing the hand on the forehead - soothes;

- Holding hands - strengthens the bond between parent and child;

- if nervous, soothe by stroking the chest, hug.

Our Prophet Muhammad (peace and blessings of Allah be upon him) was an example to all in the matter of kindness.

By following these tips, make it a habit to express your love to your child sincerely and fully. By making the child feel what a great blessing kindness is, a strong stable bond develops between you so that he or she grows up to be a real person with good manners, obedient, respectful of adults, respectful of the little ones, and pleasing to their parents in the presence of you and others.

\section{REFERENCES}

1. Zhuraev M., Umarov Sh. R., Kholmatov D. I., Kuchkarov, U. (2010). Description of varieties, hybrids and forms of mulberry, created in the Republic of Uzbekistan and included in the world collection of mulberry. Tashkent, 2010, $4 \mathrm{p}$.

2. Mirziyoev Sh.M. (2017). We will build our great future together with our brave and noble people. Tashkent, Uzbekistan Publishing House, 2017.

3. Family encyclopedia. (2019). Tashkent, "National encyclopedia of Uzbekistan" State Scientific Publishing House.

4. Haydarov I.O. (1996). Individual and social psychological features of the pupils of the orphanage. Abstract of Diss. Candidate of psychological Science. $19 \mathrm{p}$.

5. The Holy Quran. (1992). Tashkent, Cholpon Publishing House, Translated by Alouddin Mansur, pp. 5-10.

6. Shoumarov G'.B. Khudoikulova H. (2014). Sociopsychological aspects of the expression of kindness in interpersonal relationships. Journal of Modern Education, pp. 38-43.

7. Yadov V.A. (1998). Sociological research strategy. Moscow: Dobrosvet.

8. Annotated Dictionary of the Uzbek Language (5 volumes). (2006). Tashkent, "National Encyclopedia of Uzbekistan” State Scientific Publishing House.

9. Avlayev O.U (2017). Educational methods Methodological manual. Tashkent, Tashkent state agrarian university, $206 \mathrm{p}$.

10. Dew J. (1999): Psychology and pedagogy of thinking (How do we think) (pp. 41-47). Transate from English. - Moscow, 187 p. 